\title{
PENGEMBANGAN PENDIDIKAN MORAL, KARAKTER, DAN KEPEMIMPINAN SISWA SMA/SMK MELALUI KEGIATAN I GLOW I BRO DI KABUPATEN BANYUWANGI
}

\author{
Sari Wiji Utami" ${ }^{\# 1}$, Mustofa Hilmi*2, Ahmad Azmi Khoirul Umam"3 \\ Program Studi Teknologi Pengolahan Hasil Ternak, Politeknik Negeri Banyuwangi, \\ Jl. Raya Jember Km. 13, Labanasem, Kabat, Banyuwangi \\ ${ }^{1}$ sariwijiutami@poliwangi.ac.id \\ 2mustofahilmi@poliwangi.ac.id \\ 3ahmadazmi@ poliwangi.ac.id
}

\begin{abstract}
ABSTRAK
Kemerosotan nilai moral di kalangan pemuda yang marak terjadi saat ini, mendorong komunitas pemuda di kabupaten Banyuwangi yang tergabung dalam komunitas Mata Indonesia, menyelenggarakan kegiatan untuk mengangkat permasalahan tersebut dari sudut pandang keilmuan dan para pakar di bidangnya. Indonesian Girls Leading Our World Indonesian Boys Respect Others (I GLOW I BRO) merupakan rangkaian kegiatan pengembangan kepribadian, sifat kepemimpinan dan organisasi, outbond, dan kemah tahunan yang awalnya diprakarsai oleh relawan Peace Corps Amerika Serikat sejak tahun 2012 di berbagai daerah di pulau Jawa. Kegiatan ini berfokus pada daya kepemimpinan dan kerjasama, serta mengaitkannya dengan kesetaraan gender. Kegiatan ini diselenggarakan untuk membahas isu-isu atau berbagai permasalahan di lingkungan sekitar, sehingga para pemuda dapat menempatkan diri dan mawas terhadap kondisi lingkungan sekitar, seiring dengan berbagai perubahannya. Kegiatan ini dilakukan dalam beberapa tahapan dan alur pelaksanaan yang meliputi penentuan materi kegiatan dan metode, survey lokasi dan sarana kegiatan, mempersiapkan sarana dan prasarana kegiatan, rekruitmen peserta, pelaksanaan kegiatan yang mencakup kegiatan indoor (pemaparan materi, sharing, serta diskusi) dan outdoor (outbond). Setelah mengikuti kegiatan ini, para pelajar SMA/SMK sederajat diharapkan dapat memiliki kemampuan dan mengembangkan karakter, pengetahuan tentang moral dan kepemimpinan, serta menerapkannya dalam kehidupan sehari-hari di masyarakat. Selain itu, peserta kegiatan ini diharapkan dapat meningkatkan kepercayaan dirinya dan membangun kerjasama dalam kelompok (teamwork) melalui kegiatan outbond yang dilaksanakan.
\end{abstract}

Keyword- Kepemimpinan, pendidikan karakter, pendidikan moral, siswa SMA/SMK

\section{PENDAHULUAN}

Moral pemuda Indonesia dari tahun ke tahun terus mengalami penurunan kualitas dalam segala aspek moral, mulai dari tutur kata, cara berpakaian, cara bersikap, dan lain sebagainya. Faktor yang mempengaruhi moral pemuda, salah satunya adalah arus globalisasi dengan segala kecanggihan teknologi yang terus berkembang. Kurangnya kesadaran dari penikmat globalisasi menyebabkan kemunduran moral pada pemuda saat ini.
Berbagai kejadian negatif tersebut dianggap melanggar, baik peraturan, etika, dan moral bangsa Indonesia yang dikenal memiliki karakter ramah, bergotong royong dengan azas persatuan, dan kesatuan, serta sila-sila lainnya dalam Pancasila. Hal tersebut menimbulkan pertanyaan masalah efektivitas pendidikan, dimana pendidikan moral menjadi salah satu bagian pembelajaran dalam pembentukan karakter pemuda (Gunadi, 2013). 
Pada saat anak memasuki masa remaja, muncul suatu tahap baru dalam perkembangan moral yang disebut dengan moralitas autonomi, muncul dari interaksi status yang seimbang dalam hubungan di antara teman sebaya. Melalui hubungan dengan teman sebaya, anak memperoleh pengertian tentang keadilan, perhatian terhadap hak orang lain, persamaan hak, dan hubungan manusia. Moralitas autonomi digambarkan sebagai moralitas atas dasar persamaan dan demokrasi yang dinamakan dengan moralitas kerjasama (Ibda, 2011).

Undang-undang Sistem Pendidikan Nasional nomor 20 tahun 2003 pasal 1 ayat (1) menyatakan "Pendidikan adalah usaha sadar dan terencana untuk mewujudkan suasana belajar dan proses pembelajaran agar peserta didik secara aktif mengembangkan potensi dirinya untuk memiliki kekuatan spiritual keagamaan, pengendalian diri, kepribadian, kecerdasan, akhlak mulia, serta keterampilan yang diperlukan dirinya, masyarakat,

bangsa dan negara". Pendidikan moral adalah suatu usaha sadar yang dilakukan oleh manusia (orang dewasa) yang terencana untuk memberikan kesempatan kepada generasi penerus menanamkan nilai-nilai ketuhanan, estetik dan etika, nilai baik dan buruk, benar dan salah, mengenai perbuatan, sikap dan kewajiban, akhlaq mulia, budi pekerti luhur agar mencapai kedewasaannya dan bertanggungjawab (Nawawi, 2010).

Pendidikan karakter tidak hanya mengajarkan mana yang benar dan mana yang salah kepada anak, tetapi juga menanamkan kebiasaan (habituation) tentang yang baik, sehingga peserta didik paham, mampu merasakan, dan mau melakukan yang baik. Pendidikan karakter membawa misi yang sama dengan pendidikan akhlak atau pendidikan moral. Melalui pendidikan karakter sekolah harus berpretensi untuk membawa peserta didik memiliki nilai-nilai karakter mulia seperti hormat dan peduli pada orang lain, tanggung jawab, jujur, memiliki integritas, dan disiplin. Pendidikan karakter juga harus mampu menjauhkan peserta didik dari sikap dan perilaku yang tercela dan dilarang.

Pendidikan moral dan karakter ini menjadi salah satu topik yang menarik untuk dikaji. Fokus masalah dalam kegiatan pengabdian ini adalah bagaimana mengembangkan dan menerapkan pembelajaran moral, karakter, dan kepemimpinan, khususnya kepada para pelajar SMA/SMK sederajat di kabupaten Banyuwangi. Kegiatan yang dapat dilakukan dalam bentuk penyampaian materi, diskusi, sharing, serta kegiatan outbond.

Kemerosotan nilai moral di kalangan pemuda yang marak terjadi saat ini, mendorong komunitas pemuda Banyuwangi yang tergabung dalam komunitas Mata Indonesia dan relawan Peace Corps Amerika Serikat sebagai penyelenggara kegiatan untuk mengangkat permasalahan tersebut dari sudut pandang keilmuan dan para pakar di bidangnya. Mengingat pentingnya pembahasan isu-isu dan fokusnya pelatihan pada kegiatan ini, maka penyelenggara memisahkan peserta sesuai dengan gender saat penyampaian materi agar penyampaian materi dapat lebih optimal dan kondusif.

Indonesian Girls Leading Our World Indonesian Boys Respect Others (I GLOW I BRO) merupakan rangkaian kegiatan pengembangan moral, karakter, sifat kepemimpinan dan organisasi, outbond, dan kemah tahunan yang awalnya diprakarsai oleh relawan Peace Corps (Amerika Serikat) sejak tahun 2012 di berbagai daerah di pulau Jawa. Sesuai dengan namanya, kegiatan ini berfokus pada daya kepemimpinan dan kerjasama, serta mengaitkannya dengan kesetaraan gender. Kegiatan ini diselenggarakan untuk membahas isu-isu atau permasalahan-permasalahan di lingkungan sekitar, sehingga para pemuda (dalam hal ini pelajar SMA/SMK sederajat) dapat menempatkan diri dan mawas terhadap kondisi lingkungan sekitar, seiring dengan berbagai perubahannya. 
Kegiatan ini telah berlangsung selama dua tahun dan akan kembali dilaksanakan pada tahun-tahun berikutnya mengingat banyaknya sisi positif yang didapatkan atas penyelenggaraan kegiatan ini. Komunitas Mata Indonesia menjadikan kegiatan ini sebagai program kerja rutin tahunan yang dimulai sejak tahun 2015. I GLOW I BRO bertujuan untuk memberikan wawasan dan implementasi teknik kepemimpinan. Kegiatan ini juga berfokus pada perubahan pola pikir pemuda terutama dalam bidang karier.

\section{TARGET DAN LUARAN}

Target kegiatan I GLOW I BRO ini adalah upaya untuk meningkatkan kualitas Sumber Daya Manusia di kabupaten Banyuwangi dalam menghadapi tantangan Masyarakat Ekonomi Asean (MEA) melalui kegiatan pengembangan pendidikan moral, karakter, dan kepemimpinan. Peserta kegiatan ini adalah pelajar SMA/SMK sederajat yang ada di kabupaten Banyuwangi.

Luaran yang dihasilkan adalah peserta kegiatan I GLOW I BRO dapat memiliki kemampuan dan mengembangkan moral, karakter, pengetahuan tentang kepemimpinan, serta menerapkannya dalam kehidupan sehari-hari di masyarakat. Selain itu, peserta kegiatan dapat meningkatkan kepercayaan dirinya dan membangun kerjasama dalam kelompok (teamwork) melalui kegiatan outbond yang dilaksanakan. Selain itu, luaran yang ditargetkan oleh tim berupa artikel ilmiah yang dipublikasikan pada jurnal pengabdian kepada masyarakat.

\section{METODE PELAKSANAAN}

Kegiatan I GLOW I BRO dilakukan dalam beberapa tahapan dan alur pelaksanaan yang meliputi:

1. Penentuan materi kegiatan dan metode

Kegiatan ini diawali dengan menentukan materi kegiatan dan metode oleh penyelenggara kegiatan antara lain pemuda-pemudi yang tergabung dalam komunitas pemuda Mata Indonesia di kabupaten Banyuwangi, relawan Peace Corps
Amerika Serikat, serta tenaga pendidik Politeknik Negeri Banyuwangi yang memiliki kepedulian terhadap kondisi saat ini. Tujuan kegiatan ini adalah untuk mengetahui karakteristik dan pengetahuan calon peserta, dalam hal ini adalah para pelajar SMA/SMK sederajat di kabupaten Banyuwangi. Diskusi ini dilakukan sebagai media untuk menyamakan persepsi penyelenggara kegiatan untuk mengangkat tema pengembangan pendidikan moral, karakter, dan kepemimpinan, serta penggunaan metode pembelajaran yang efektif.

Setelah mengetahui permasalahan di lapang, tim pengabdian menawarkan solusi dengan cara berperan aktif dalam memberikan materi pengembangan pendidikan moral, karakter, dan kepemimpinan, serta kegiatan outbond untuk meningkatkan minat dan keterampilan calon peserta yang didukung oleh pihak penyelenggara kegiatan.

2. Survey lokasi dan sarana kegiatan

Kegiatan survey perlu dilakukan untuk mengidentifikasi lokasi dan sarana kegiatan yang tersedia, serta dapat mendukung pelaksanaan kegiatan I GLOW I BRO, dengan datang langsung ke sekolah-sekolah SMA/SMK sederajat di kabupaten Banyuwangi yang memiliki kemudahan akses jalan/transportasi dan tempat ibadah, aula dan lapangan untuk kegiatan outbond, serta sarana dan prasarana lainnya. Lokasi kegiatan I GLOW I BRO ini dilaksanakan di SMK Negeri Ihya' Ulumuddin di kecamatan Singojuruh, kabupaten Banyuwangi.

3. Rekruitmen peserta

Kegiatan rekruitmen peserta dilakukan dua bulan sebelum pelaksanaan kegiatan I GLOW I BRO, melalui undangan ke sekolah SMA/SMK sederajat di kabupaten Banyuwangi, maupun melalui media sosial (Facebook, Instagram, Whatsapp, dan sebagainya). Para peserta adalah pelajar siswa dan siswi SMA/SMK 
sederajat yang ada di kabupaten Banyuwangi.

4. Pelaksanaan kegiatan

Kegiatan I GLOW I BRO ini berlangsung selama dua hari di SMK Negeri Ihya' Ulumuddin di kecamatan Singojuruh, kabupaten Banyuwangi. Pada hari pertama, para peserta mendapatkan materi dalam ruangan (indoor), yang mencakup materi tentang pendidikan karakter dan kepemimpinan, disertai dengan sharing dan diskusi. Peserta dibagi menjadi beberapa kelompok untuk memudahkan dalam pengerjaan tugas dan diskusi yang diberikan. Pada hari kedua, peserta melaksanakan kegiatan outbond baik di dalam maupun luar ruangan.

5. Hasil dan luaran

Hasil dan luaran kegiatan ini menyangkut hasil yang diperoleh dalam kegiatan tersebut, secara rinci dijelaskan sebagai berikut:

a. Sertifikat bagi peserta dan penyelenggara.

b. Peningkatan kualitas Sumber Daya Manusia (pelajar SMA/SMK sederajat) dalam hal pembentukan moral, karakter, dan kepemimpinan, serta peningkatan rasa percaya diri dan membangun kerjasama dalam kelompok (teamwork).

c. Artikel ilmiah yang dipublikasikan pada jurnal pengabdian kepada masyarakat.

\section{HASIL DAN PEMBAHASAN}

Manusia memiliki ciri khas yang secara prinsip berbeda dari ciptaan Tuhan yang lainnya. Salah satu perbedaan yang sangat tampak dalam kehidupan manusia adalah cara hidup yang penuh dengan nilai-nilai etika dan luhur dalam kehidupannya. Tujuan pendidikan memuat gambaran tentang nilai-nilai yang baik, luhur, pantas, benar, dan indah untuk kehidupan (Tanyid, 2014).

Perkembangan moral dipengaruhi oleh cara dan nilai-nilai dalam membesarkan anak. Nilai-nilai ini ditentukan oleh budaya suatu bangsa atau suku. Budaya dikatakan dapat mengkomunikasikan standar etika dan pembentukan, serta penguatan kebiasaan perilaku yang baik pada pertumbuhan anak. Anak diharapkan belajar aturan, mengalami ketidakenakan emosi ketika melanggar aturan moral, serta merasakan kepuasan ketika mematuhinya (Ibda, 2011).

Aspek lain yang dapat dikembangkan untuk menanamkan perilaku moral pada anak adalah melalui penerapan disiplin. Disiplin merupakan suatu cara untuk mengajarkan anak berperilaku moral yang sesuai dengan harapan sosial. Tujuan penerapan kedisiplinan ini adalah untuk membentuk perilaku sehingga sesuai dengan budaya, dimana seorang individu itu hidup dan tinggal.

Perilaku moral yang sesungguhnya tidak hanya sesuai dengan standar sosial, tetapi harus dilakukan dengan tulus didasarkan pada dorongan hati nurani. Perilaku moral harus dikembangkan untuk memiliki keinginan melakukan suatu perbuatan yang baik dan menjauhkan perbuatan yang buruk. Seiring dengan perkembangannya, anak juga harus diberikan pemahaman mengapa hal ini dikatakan "benar" dan hal itu dikatakan "salah".

Pemuda sebagai generasi penerus bangsa memiliki peran dan posisi yang strategis. Mereka merupakan harapan masa depan bangsa. Maju atau mundurnya bangsa dan negara ada di pundak mereka. Sudut pandang psikologi para pemuda sebagai generasi penerus memiliki potensi yang bisa dikembangkan secara maksimal. Potensi mereka yang prospektif, dinamis, energik, penuh vitalitas, patriotisme, dan idealisme harus dikembangkan melalui pendidikan dan pelatihan yang terencana dan terprogram (Nawawi, 2010).

Pemuda sebagai generasi penerus juga memiliki kemampuan potensial yang bisa diolah menjadi kemampuan aktual. Mereka juga memiliki potensi kecerdasan intelektual, emosi dan sosial, berbahasa, serta kecerdasan seni yang bisa diolah menjadi kecerdasan aktual yang dapat membawa mereka kepada prestasi yang tinggi dan kesuksesan. 
Pemuda memiliki potensi moral yang dapat diolah dan dikembangkan menjadi moral yang positif sehingga mampu berpartisipasi aktif dalam pembangunan bangsa dan negara yang penuh dengan kejujuran, tidak korup, semangat yang tinggi, dan bertanggungjawab. Hal itu bisa terwujud apabila semua potensi mereka dikembangkan dan salah satunya adalah potensi moral. Oleh karena itu, pemuda sebagai generasi penerus harus diselamatkan melalui pendidikan nilai moral, sehingga harkat dan martabat bangsa bisa terangkat, kualitas hidup meningkat, dan kesejahteraan, serta kenyamanan pun bisa didapat.

Orang yang terdidik memiliki kesadaran tentang dari mana asal mula dan tujuan kehidupan. Berdasar kesadaran tersebut, manusia harus kreatif dan produktif dalam menjalani kehidupan dan mau bersikap dan berperilaku adil di sepanjang hidupnya. Nilai-nilai moral dan etika perlu ditanamkan di dunia pendidikan dan dikembangkan di dalam kehidupan sosial pada umumnya. Masyarakat seharusnya berkarakteristik mendidik agar dinamika sosial berkembang menurut dorongan moral (hati nurani individual) dan nilai-nilai etika sebagai satu kesatuan sistem. Setiap individu harus sadar atas kewajiban sosial apa yang harus dilakukan demi keutuhan masyarakatnya, dan masyarakat secara etis bertanggung jawab atas kewajiban setiap individu tersebut. Itulah landasan dasar pendidikan untuk mendirikan sebuah masyarakat terdidik, masyarakat berbudaya yang berkeadilan (Suhartono, tanpa tahun).

Pada era dengan kompleksitas problema dan tantangan seperti saat ini, terutama dengan majunya dunia teknologi, informasi, dan komunikasi, sendi-sendi etika dan moral harus dijaga dan terus diupayakan eksistensinya. Pendidikan merupakan salah satu garda terdepan yang harus dijaga demi terwujudnya tujuan negara yang sudah dirumuskan dalam Pembukaan UUD 1945. Pemerintah juga harus berkomitmen untuk membangun bangsa dan negara yang berkarakter.

Seorang pemimpin harus menerapkan gaya kepemimpinan untuk mengelola bawahannya, karena seorang pemimpin akan mempengaruhi keberhasilan organisasi dalam mencapai tujuannya. Gaya kepemimpinan adalah perilaku atau cara yang dipilih dan dipergunakan pemimpin dalam mempengaruhi pikiran, perasaan, sikap, dan perilaku para anggota organisasi (Tampi, 2014). Gaya kepemimpinan dan motivasi secara simultan juga mempunyai pengaruh signifikan terhadap kinerja (Sariadi, 2013).

Banyak variabel yang dapat dianggap mempengaruhi kinerja (performance) kelompok selain kepemimpinan. Faktor kepemimpinan sangat diperlukan untuk mengkolaborasi suatu kelompok kerja (teamwork) guna mencapai suatu tujuan organisasi. Faktor yang sangat berperan adalah kepemimpinan dalam membentuk tim yang baik. Seorang pemimpin diharapkan dapat berperan sebagai figur yang menggerakkan bawahannya dan rasional, penuh inisiatif, serta kecerdasan dalam pengambilan keputusan dan mampu dalam memecahkan masalah yang pada akhirnya dapat meningkatkan kinerja (Marpaung, 2014).

Seorang yang memiliki karakter pemimpin, memerlukan syarat-syarat sebagai berikut (Wardani, 2014):

a. Kelenturan budaya (cultural flexibility), kelenturan budaya tidak hanya untuk mengelola, tetapi persyaratan ini juga untuk mengenali dan menerima perbedaan-perbedaan yang ada dalam organisasi.

b. Keterampilan berkomunikasi (communication skills), pemimpin yang efektif harus mampu berkomunikasi, baik secara tertulis, lisan maupun secara non verbal.

c. Ketrampilan dalam mengelola Sumber Daya Manusia (HRD Skills), yaitu berkaitan dengan pemimpin dalam usahanya untuk meningkatkan suasana pembelajaran, merancang program pelatihan, menyebarkan informasi dan pengalaman, meramalkan hasil akhir, 
mengadakan konseling karir, menciptakan perubahan organisasi, dan menyesuaikan diri dengan semua pihak.

d. Kreativitas (creativity), tidak hanya dimiliki oleh pemimpin itu sendiri, melainkan sebagai pemimpin.

Keberhasilan pencapaian tujuan tergantung kepada individu yang ada dalam kelompok kerja (teamwork) terutama pada pimpinannya. Kelompok kerja terdiri dari sekelompok orang dengan kemampuan, talenta, pengalaman, dan latar belakang yang berbeda dan berkumpul bersama untuk mencapai satu tujuan. Meskipun terdapat perbedaan di antara mereka, namun tujuan bersama merupakan penghubung yang menyatukan sebagai suatu kelompok kerja (Marpaung, 2014).

Kegiatan I GLOW I BRO ini berlangsung selama dua hari di SMK Negeri Ihya' Ulumuddin yang beralamat di jalan K.H. Abdullah Hasbullah nomor 8 desa Padang, kecamatan Singojuruh, kabupaten Banyuwangi pada tanggal 27-28 Januari 2018. Penentuan waktu pengabdian mengacu pada kalender tahun ajaran sekolah.

Kegiatan ini diikuti oleh 62 peserta yang berasal dari tujuh SMA/SMK sederajat, sebagai berikut:

1. 17 siswa/siswi SMKN Ihya' Ulumuddin

2. 13 siswa/siswi SMAN 1 Wongsorejo

3. 10 siswa/siswi SMK Muhammadiyah 8 Siliragung

4. 6 siswa/siswi MAN Pesanggaran

5. 4 siswa/siswi SMK Muhammadiyah Rogojampi

6. 7 siswa/siswi SMAN 1 Bangorejo

7. 5 siswa/siswi SMAN 1 Pesanggaran

Pada hari pertama, para peserta mendapatkan materi dalam ruangan (indoor), yang mencakup materi tentang pendidikan moral, karakter, dan kepemimpinan, disertai dengan sharing, presentasi, dan diskusi. Peserta dibagi menjadi beberapa kelompok untuk memudahkan dalam pengerjaan tugas dan diskusi yang diberikan. Pada hari kedua, peserta melaksanakan kegiatan outbond baik di dalam maupun luar ruangan.

Kegiatan outbond yang dilakukan mencakup beberapa jenis permainan individu maupun kelompok yang dapat meningkatkan keterampilan peserta, diantaranya:

1. Ice breaking, digunakan untuk menghilangkan ketegangan peserta dan menstimulus antusiasme peserta untuk siap mengikuti seluruh kegiatan berikutnya. Kegiatan ice breaking diantaranya pencanangan komitmen kegiatan (goal setting), pembagian kelompok, serta pendelegasian tugas pertama, membuat yel-yel dan lagu kelompok.

2. Longest train, permainan ini bertujuan untuk meningkatkan kerjasama antaranggota dalam tim, mengatur strategi dan kreativitas, serta menempatkan diri sesuai dengan kemampuan yang dimiliki.

3. Nails in the bottle, permainan ini bertujuan untuk meningkatkan kerjasama antaranggota dalam tim, mengatur strategi, menumbuhkan sifat kepemimpinan dalam suatu kelompok atau organisasi.

4. Water relay, permainan ini bertujuan untuk meningkatkan kerjasama antaranggota dalam tim, meningkatkan ketangkasan individu, mengatur strategi, serta menempatkan diri sesuai dengan kemampuan yang dimiliki.

5. Pipe line, permainan ini bertujuan untuk meningkatkan kerjasama antaranggota dalam tim, mengatur strategi, menumbuhkan sifat kepemimpinan dalam suatu kelompok atau organisasi, serta meningkatkan ketangkasan individu. 


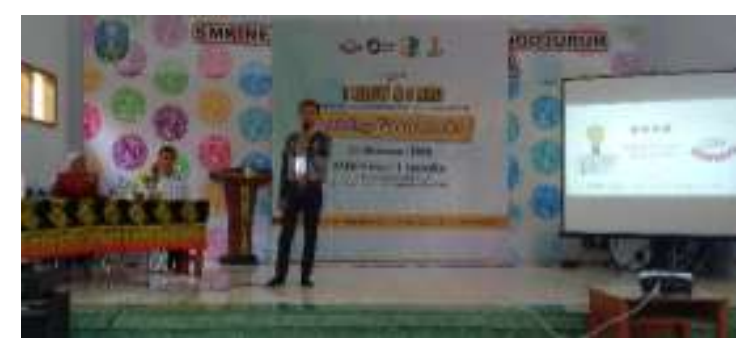

Gambar 1. Sesi penyampaian materi moralitas, pembentukan karakter, dan kepemimpinan

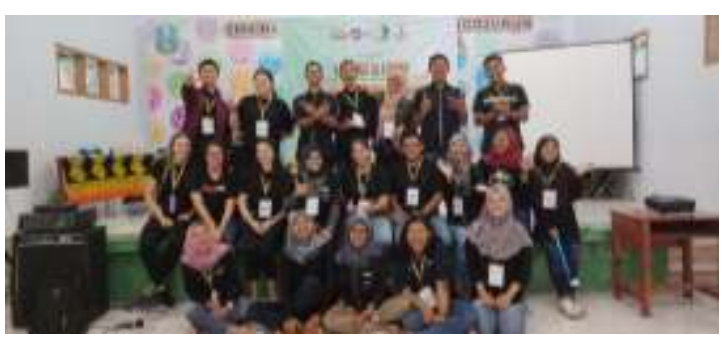

Gambar 2. Tim pelaksana kegiatan

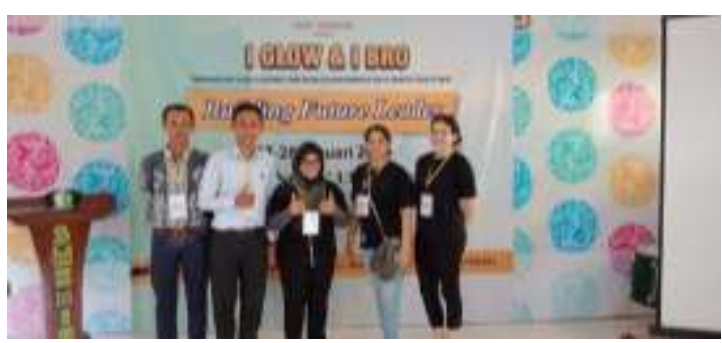

Gambar 3. Pemateri kegiatan

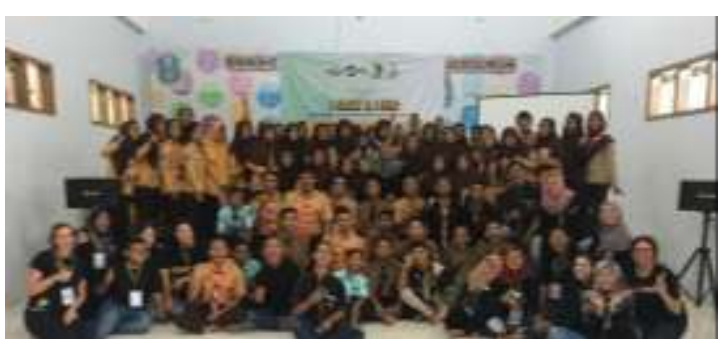

Gambar 4. Seluruh peserta kegiatan I GLOW I BRO dari berbagai SMA/SMK Banyuwangi

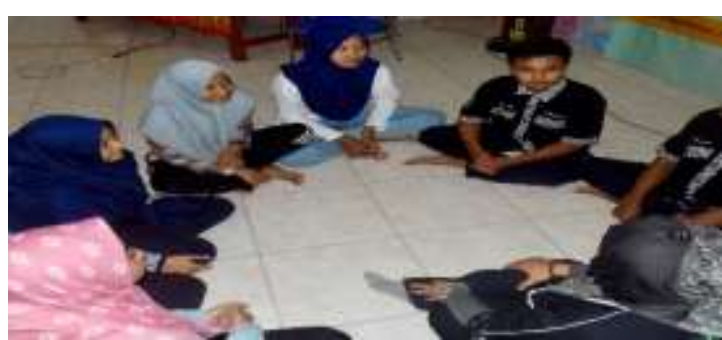

Gambar 5. Sesi diskusi kelompok tentang karakter dan kepemimpinan

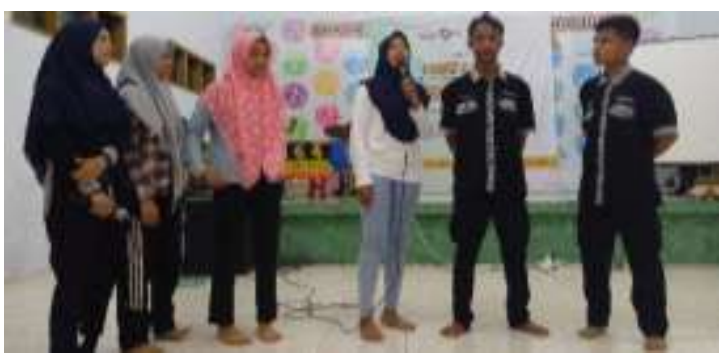

Gambar 6. Sesi presentasi kelompok tentang karakter dan kepemimpinan

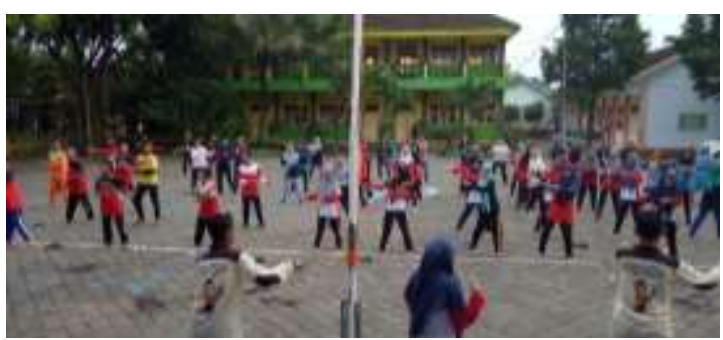

Gambar 7. Kegiatan outbond

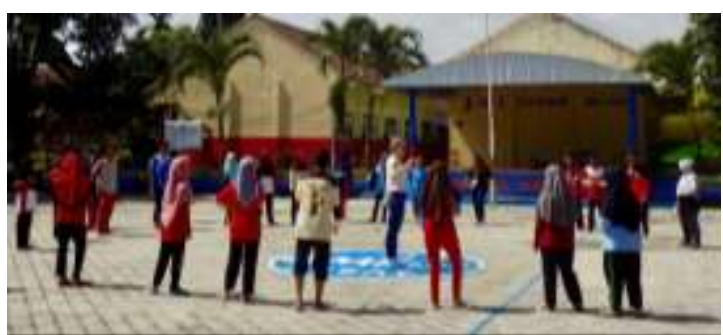

Gambar 8. Kegiatan outbond

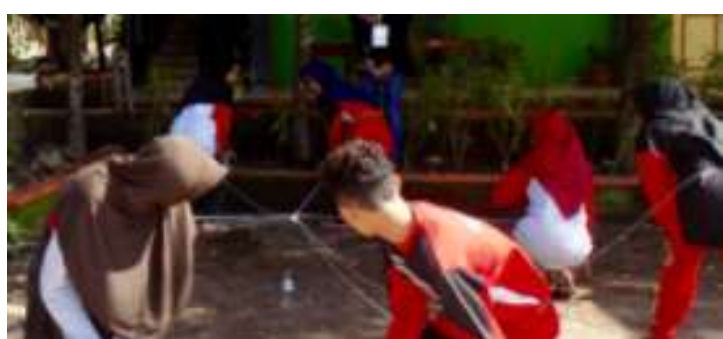

Gambar 9. Kegiatan outbond

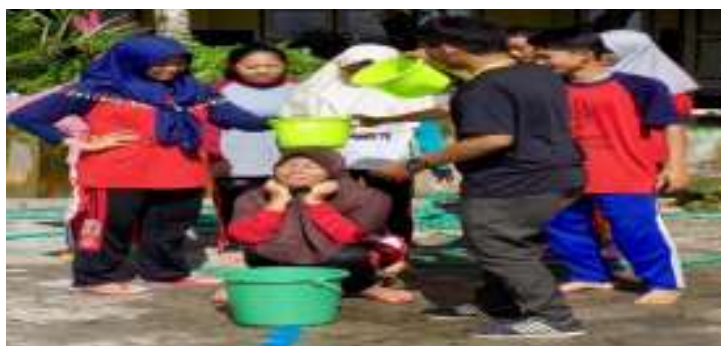

Gambar 10. Kegiatan outbond 


\section{KESIMPULAN DAN SARAN \\ Kesimpulan}

Berdasarkan kegiatan kegiatan I GLOW

I BRO yang telah dilakukan oleh tim pelaksana, dapat disimpulkan bahwa melalui kegiatan ini, para peserta pelajar SMA/SMK sederajat dapat memperoleh tambahan pengetahuan dan peningkatan keterampilan dalam pengembangan moral, karakter, dan kepemimpinan untuk dapat diterapkan dalam kehidupan sehari-hari.

\section{Saran}

1. Kegiatan pengabdian serupa hendaknya sering diselenggarakan, tidak hanya di kalangan pemuda, tetapi juga pada anak sejak usia dini dan remaja (pelajar SMP sederajat).

2. Dibutuhkan komitmen bersama dan kerjasama kondusif dari banyak pihak demi terwujudnya generasi penerus yang berkarakter dan memiliki sifat kepemimpinan di semua jenjang pendidikan.

\section{UCAPAN TERIMA KASIH}

Ucapan terima kasih kami sampaikan kepada pihak komunitas pemuda Mata Indonesia di kabupaten Banyuwangi, teman-teman relawan Peace Corps Indonesia (Sylvia Silva, Andres Avellaneda, Mari D., Lisa Christensen, Tori Blanchard, Sapphire Carter) serta seluruh pihak yang telah menyelenggarakan dan mendanai kegiatan ini.

\section{DAFTAR PUSTAKA}

Gunadi, R.A.A. 2013. Membentuk karakter melalui pendidikan moral pada anak usia dini di Sekolah Raudhatul Athfal (R.A.) Habibillah. Jurnal Ilmiah Widya. 1(2): 85-91.

Ibda, F. 2011. Perkembangan moral pada anak dan relevansinya dengan pendidikan. Jurnal Ilmiah Didaktita. 9(2): 380-391.

Marpaung, M. 2014. Pengaruh kepemimpinan dan team work terhadap kinerja karyawan di Koperasi Sekjen Kemdikbud Senayan Jakarta. Jurnal Ilmiah Widya. 2(1): 33-40.
Nawawi, A., P.L.B., 2011. Pentingnya Pendidikan Nilai Moral bagi Generasi Penerus. Jurnal kependidikan: insania, 16(2), pp.119-134.

Sariadi, S. 2013. Gaya kepemimpinan dan motivasi pengaruhnya terhadap kinerja pegawai pada bagian sekretariat TNI AL Lantamal VIII di Manado. Jurnal Emba. 1(4): 31-39.

Suhartono, S., 2013. Kesadaran Moral Kehidupan Bermasyarakat: Suatu Pemikiran Kefilsafatan.

Tampi, B. J. 2014. Pengaruh gaya kepemimpinan dan motivasi terhadap kinerja karyawan pada PT. Bank Negara Indonesia,Tbk. (Regional Sales Manado). Jurnal Acta Diurna. 3(4): 120.

Tanyid, M. 2014. Etika dalam pendidikan: Kajian etis tentang krisis moral berdampak pada pendidikan. Jurnal Jaffray. 12(2): 235-250.

Wardani, L.K., 2014. Pengaruh Kepemimpinan, Motivasi Kerja dan Komitmen Organisasi terhadap Kepuasan Kerja dalam meningkatkan Kinerja Guru SMP Negeri Kota Tegal (Doctoral dissertation, UNIVERSITAS DIAN NUSWANTORO). 